\title{
Fundamentalismo: Escritura e Teologia entre fé e razão
}

\author{
Maria de Lourdes Corrêa Lima
}

\begin{abstract}
O fundamentalismo é hoje uma questão relevante, senão a grande questão do século XXI. Está presente em numerosos grupos, de tendências variadas, inclui elementos diversos e indica, em seu uso largo, uma perspectiva religiosa, uma cosmovisão, uma filosofia, uma teoria política, caracterizada pelo radicalismo de seus princípios e pela militante utilização de meios violentos para expansão de seus princípios. Designa por vezes grupos religiosos denominados "conservadores" ou grupos populares, ligados ou não a ideias religiosas, que professam ideologias radicais e intolerantes. Renunciando a uma investigação exaustiva do fenômeno, o interesse do presente estudo diz respeito ao fundamentalismo cristão em sua perspectiva religiosa. O tema será tratado teoricamente, em seus princípios, não se detendo numa particular manifestação. A perspectiva é particularmente bíblica e teológica. A finalidade é compreender o fenômeno, seu aparecimento e desenvolvimento, traçar suas principais características e apontar possíveis ganhos e problemas. Pretende-se ainda aprofundar algumas das principais questões envolvidas.

Sendo um dado apontado como preocupante no mapa religioso nas últimas décadas, tanto mais transparece a relevância da temática.
\end{abstract}

\section{O fenômeno, seu surgimento e desenvolvimento}

A origem do termo remonta a uma determinada forma de conceber e viver a fé cristã cunhada por parte de algumas igrejas protestantes (particularmente presbiterianas) dos Estados Unidos entre o final do século 
XIX e primeiras décadas do século XX. É neste sentido restrito que o termo será empregado aqui e que será abordada a temática ${ }^{1}$.

\subsection{Das origens até a primeira grande guerra ${ }^{2}$}

O progresso das ciências naturais e humanas levou, na segunda metade do século XIX, a uma crise cultural e religiosa. As investigações sobre a formação do planeta, do aparecimento da vida e a origem e evolução das espécies, de um lado, e a formulação de teorias sociológicas, de outro, bem como as descobertas arqueológicas (resquícios monumentais, objetos e escritos antigos) e uma nova impostação da história como ciência desenvolveram-se num clima marcado pelo materialismo e ateísmo, em oposição mais ou menos explícita à fé. Apresentando-se seus dados como indiscutíveis e em confronto com os relatos bíblicos, parecia-se pôr em questão a veracidade e plausibilidade da palavra bíblica, fazendo emergir numerosos problemas para os fiéis. As descobertas sobre a formação da terra, por exemplo, colocavam em questão a cronologia baseada em Gênesis; a teoria evolucionista era posta como alternativa aos relatos bíblicos da criação. No campo da sociologia, desenvolveu-se a teoria de uma evolução social progressiva que entrava em confronto com a ideia de pecado original ${ }^{3}$. O maior conhecimento da história antiga e das línguas e literatura do Antigo Oriente Próximo levou ao desenvolvimento da crítica textual e da análise literária dos textos bíblicos, com a formulação paulatina das diversas etapas do chamado método histórico-crítico. O conhecimento de textos extra-bíblicos aparentados aos relatos da Escritura levou a relativizar o conceito de revelação e inspiração. Pôs também em questão, em grande escala, a historicidade e veracidade dos relatos do Antigo e Novo Testamento e, com isto, a autoridade da Escritura.

$\mathrm{O}$ primeiro sinal claro de resistência às novas ideias científicas do século XIX e à análise histórica da Escritura partiu dos teólogos do Princeton Theological Seminary, que defenderam a inspiração literal da Escritura

\footnotetext{
${ }^{1}$ Sobre o fenômeno em geral, cf. E. Gellner, Pós-modernismo, razão e religião, Lisboa, 1992, que aponta o fundamentalismo religioso como uma das três grandes perspectivas existentes no pensamento pós-moderno. Sobre a caracterização do fundamentalismo religioso, cf. op.cit., 13.

${ }^{2}$ Para os dados desta primeira parte, cf. R.D. Witherup, Fundamentalismo biblico, São Paulo, 2004, 19-39; E.R. Sandeen, "Christian Fundamentalism", in www.britannica.com.

${ }^{3}$ Cf. Herbert Spencer $(1820$ - 1903). Após um período de graça, o ser humano caído no pecado teria entrado numa situação de total corrupção, sem possibilidade de renovação. Com isto, não havia mais lugar para o apelo à conversão pessoal, sendo acentuada unicamente a renovação da sociedade em seu conjunto, que pouco a pouco formaria o Reino de Deus.
} 
(entendida como ditado palavra por palavra) e defenderam a infalibilidade da Bíblia em matéria de fé e moral e sua inerrância em matéria de história e ciências naturais.

A base de tal reação encontrava-se no pensamento "evangelical", que predominava nas igrejas protestantes históricas nos Estados Unidos nesta época. Tendo surgido na Inglaterra no século XVIII, o movimento "evangelical", presente em diversos grupos, chegou aos Estados Unidos com feições próprias, mantendo, porém, o mesmo escopo de renovar o protestantismo a partir da ênfase na piedade pessoal e na militância missionária, em contraste com a sociedade de seu tempo. O movimento evangelical enfatiza fortemente o caráter individual da graça e a importância da conversão pessoal. A Escritura, interpretada com a luz pessoal do Espírito, é critério absoluto para a fé e a moral. A ética, derivada diretamente da Bíblia, visa primordialmente o indivíduo. A missão é desenvolvida com forte apelo ao emocional, à aceitação pessoal de Jesus Cristo, e tem por interesse primário o crescimento da comunidade. Sendo todo esforço teológico considerado suspeito, o movimento tem um cunho nitidamente anti-intelectualista ${ }^{5}$. Realçase grandemente a ação das forças satânicas no mundo, com a conseqüente colocação em segundo plano da liberdade humana. Como se espera para breve a parusia, o mais decisivo é a opção do crente por Jesus Cristo.

Outro ponto importante que marcou a resistência foi a concepção de história dispensacionalista ${ }^{6}$. Baseando-se em sua interpretação dos dados bíblicos, o dispensacionalismo divide a história em diversas fases (ou "dispensações") ${ }^{7}$. O período atual é o da iminente volta de Cristo, que arrebatará seus eleitos nos espaços celestes, depois do que haverá sete anos de grande tribulação. A primeira metade destes sete anos será marcada pela ação do anticristo, que estabelecerá uma falsa paz entre os povos. Nos três anos e meio seguintes, o anticristo estabelecerá uma religião oficial, mescla de diversas crenças e ideologias, e se voltará contra os convertidos que ainda não tiverem sido arrebatados. Por fim, sob seu comando, os povos se reunirão para derrotar o Cristo, que, então, retornará e aniquilará satanás, o anticristo e os

\footnotetext{
${ }^{4}$ Em lugar de "evangélico", prefere-se manter o termo mais próximo do inglês, uma vez que o termo "evangélico" designa atualmente, em geral, as diversas igrejas oriundas da reforma e outras denominações cristãs.

${ }^{5}$ Cf. F. Galindo, O fenômeno das seitas fundamentalistas, Petrópolis, 1995, 148-150.

${ }^{6}$ Defendida já anteriormente (1840), de John Nelson Darby, tais ideias se propagaram sobretudo pelo trabalho de Dwight L. Moody (1837 - 1899) e pelos institutos bíblicos fundados em diversas cidades. Foram incorporadas no comentário bíblico mais utilizado pelos fundamentalistas, o "Scofield Reference Bible" (1909), de autoria de Cyrus I. Scofield. Nos anos trinta, o dispensacionalismo foi assumido oficialmente como doutrina fundamentalista.

${ }^{7}$ Cf. F. Galindo, O fenômeno das seitas fundamentalistas, 295-300.
} 
infiéis, dando início a um reinado de mil anos em Jerusalém. Após este milênio, satanás será solto por pouco tempo, para logo ser precipitado no lago de fogo. Haverá então o último juízo e a ressurreição final ${ }^{8}$.

O relevante interesse pela segunda vinda de Cristo levou a um movimento que promoveu a Niagara Bible Conference, cujas reuniões tornaram-se anuais. Iniciando-se pouco após a morte do ministro batista da cidade de New York, James Inglis, em 1872, continuou sob a direção do ministro presbiteriano James H. Brookes (1830-1897) em St. Louis, Missouri. Pouco a pouco os líderes das diversas igrejas se agregaram a estas ideias milenaristas e, a partir de 1878, promoveram conferências em numerosas cidades. Nos últimos anos do século XIX, os milenaristas dividiram-se e, apesar dos esforços de união de Brookes, pouco após sua morte as conferências cessaram.

Na década de 1890, cresceu a reação ao modernismo e foram realizados muitos processos judiciais. Um dos mais importantes se deu contra Charles A. Briggs (1841-1913), professor do Union Theological Seminary, na cidade de New York, acusado por suas ideias acerca da inspiração verbal (1891) e que em 1893 foi suspenso do ministério de pastor.

O movimento conservador continuou suas atividades e fundou a American Bible League, em 1902. É neste contexto que, entre 1910 e 1915 a Liga publicou uma série de doze opúsculos denominados "The Fundamentals: A Testimony to the Truth", com ampla divulgação em todo o mundo. O nome da obra foi transferido para os conservadores, chamados então de fundamentalistas. Nesta obra, eram definidos os pontos "fundamentais" da fé a serem mantidos diante da ameaça das ideias modernistas: em primeiro lugar, a inspiração verbal da Escritura e sua inerrância; mas também certas verdades doutrinárias: a concepção virginal, a expiação vicária de Jesus Cristo, a ressurreição de Cristo (e consequentemente dos fiéis) e a volta gloriosa de Cristo para o julgamento.

Dada a importância da Escritura e, por conseguinte, de sua tradução para uma língua acessível (já que a compreensão deveria estar calcada num texto confiável, que não permitisse interpretações em linha modernista), muitos fundamentalistas defenderam o uso exclusivo da antiga versão inglesa de King James, na modalidade "autorizada".

\footnotetext{
${ }^{8}$ Visão pré-milenarista, distinta do pós-milenarismo, que defende que a parusia terá lugar somente após um período de mil anos de paz na terra. Por ocasião de sua vinda, Cristo recompensará seus eleitos. Cf. J.M. Court, "Millenarianism", in R.J. Coggins - J.L. Houlden (ed.), A Dictionary of Biblical Interpretation, London, 1990, 459-461, aqui 459; F. Galindo, O fenomeno das seitas fundamentalistas, 160-161.
} 


\subsection{De 1918 a 1930: luta aberta contra os modernistas-liberais}

Durante a segunda guerra, as atividades sofreram, sendo retomadas novamente após 1918. A partir de encontros nas cidades de New York e Philadelphia, foi formada a World's Christian Fundamentals Association (1919), que colocou a base para numerosas atividades posteriores. Reafirmouse a rejeição das ideias modernistas e dos ensinos escolares conexos, especialmente relativos às teorias evolucionistas. Os fundamentalistas abandonaram as universidades que se alinhavam com as tendências modernas e fundaram institutos independentes para o estudo bíblico.

Os anos de 1920 e 1921 foram marcados por muitas lutas e tensões. Muitas denominações ficaram alheias a estas controvérsias, enquanto outras se firmaram no modernismo, também porque os conservadores as deixaram para formar novas igrejas. Outras (como o congregacionalismo), não possuindo uma organização que decidisse em questões teológicas, não se alinharam oficialmente com um ou outro grupo.

As controvérsias mais sérias levaram à expulsão de pastores e sobretudo à proibição do ensino de teorias modernistas nas escolas. $\mathrm{O}$ caso mais representativo foi o do biólogo John T. Scopes (1900-1970), professor em Dayton, Tennessee, levado a julgamento por ensinar tais ideias (processo de 1925). Mais tarde foi absolvido ${ }^{9}$, mas a proibição do ensino do evolucionismo neste estado americano só caiu em 1967.

No final da década de vinte, os fundamentalistas perderam força nas igrejas. Alguns permaneceram nas suas comunidades de origem, enquanto outros fundaram comunidades novas. Outros ainda migraram para pequenos grupos. Perderam também força no ensino dos seminários e muitos se uniram em institutos bíblicos independentes e faculdades bíblicas. Muitas dentre essas instituições desenvolveram publicações, programas radiofônicos e conferências para difundir seu pensamento.

\subsection{De 1930 a 1957: reorganização e fundação de novos grupos}

Nos anos trinta, estabeleceram-se novos grupos fundamentalistas que divergiam entre si. Destacaram-se Greshan Machen e Carl McIntire (da Igreja Presbiteriana Ortodoxa), seu discípulo. Machen defendeu o separatismo frente aos modernistas, considerados heréticos e apóstatas. McIntire levou adiante o radicalismo de Machen, fundando, em 1937, a Bible Presbyterian Church (Igreja Bíblica Presbiteriana). Com isto dividiu-se o fundamentalismo, entre os

${ }^{9}$ Cf. F. Galindo, O fenômeno das seitas fundamentalistas, 173. 
mais moderados, herdeiros dos tempos anteriores, e o grupo liderado por McIntire, mais radical e separatista, facção chamada também de fundamentalismo de extrema direita ou ultra-fundamentalismo. Este processo culminou na fundação do American Council of Christian Churches (ACCC), em 1941.

As posições fundamentalistas apareceram aos observadores sempre mais como anti-intelectualistas, avessas à ciência e à cultura. No entanto, no final da década de trinta, os principais grupos fundamentalistas distinguiam-se dos radicais por se alinharem, em parte, com a investigação acadêmica e as tendências científicas e culturais, diferindo assim dos separatistas. Formaram então o movimento "neo-evangelical", que criou um centro de estudos na Califórnia (Pasadena), o Fuller Theological Seminary. Em 1942, formou-se no âmbito deste tipo de fundamentalismo uma organização ecumênica, a National Association of Evangelicals ${ }^{10}$. Líder deste grupo moderado foi Billy Graham, que se destacou por sua pregação e pela utilização dos meios de comunicação de massa.

Ainda em 1942 houve uma tentativa de união dos dois grupos, mas que não deu resultado. A ruptura final se deu em 1957, quando os neo-evangelicais foram considerados traidores pelo grupo extremado. Os radicais ficaram sempre mais à margem, mas continuaram a desenvolver-se a partir de alguns de seus líderes. Fundaram centros de estudo com esta orientação, dentre os quais destacam-se: a Bob Jones University, fundada em 1927 na Flórida e que, após um período funcionando no Tennessee, estabeleceu-se na Carolina do Sul (1947); a Liberty University (Virgínia), fundada em 1971; a Regent University, fundada em 1978. O grupo radical difundiu-se também através de programas televisivos, chegando a dominar o cenário nos anos setenta.

\subsection{A partir de 1960: militância política}

Os anos sessenta viram novos confrontos entre fundamentalistas e modernistas, particularmente quanto à questão do ensino nas escolas públicas da teoria da evolução, seja excluindo o seu ensinamento, seja exigindo que, a seu lado, fosse ensinado o criacionismo (leitura literalista do relato do Gênesis). Desenvolve-se também uma orientação que visa estabelecer uma concordância entre os dados levantados pelas pesquisas científicas e os textos bíblicos ${ }^{11}$. Surge, nesse âmbito, uma nova tendência, que visava apresentar os

\footnotetext{
${ }^{10} \mathrm{Cf}$. F. Galindo, O fenômeno das seitas fundamentalistas, 174.

${ }^{11}$ Exemplos desta tendência podem ser vistos, por exemplo, na obra de Werner Keller, "E a Bíblia tinha razão", ou nos trabalhos de história de Israel que procuram unir arqueologia e interpretação de textos bíblicos.
} 
relatos do Gênesis em moldura científica ("scientific creationism" ou "creation science"), reformulada mais tarde, nos anos noventa ("intelligent design").

Em 1979, Jerry Falwell, da ala do fundamentalismo radical, fundou uma organização civil, a Moral Majority, com a finalidade de lutar contra a legalização do aborto, os movimentos feministas e homossexuais, e em favor da oração nas escolas. Assumiram posições políticas em vista de combater o comunismo, aumentar as defesas militares e fortalecer o estado de Israel. Estas posturas, aceitas também pelos evangélicos em geral, aproximou, no campo prático, as duas visões. Houve, no entanto, também grupos de esquerda que rejeitaram visões políticas conservadoras. Com posturas muito diferentes, ambos se baseavam na Escritura. Os de esquerda, partindo de At 2,44-45, defendiam a divisão dos bens e o igualitarismo; os de direita, defendiam ideias pacifistas e a submissão à autoridade com textos como do Sermão da Montanha, da aceitação de Jesus de sua morte, bem como Rm 13, ${ }^{12}$. No final dos anos oitenta, a organização Moral Majority foi substituída pela Christian Coalition, que assumiu uma posição politica estreitamente ligada ao partido republicano, o que continua ainda hoje. Na década de noventa houve uma certa aproximação para com a Igreja Católica, com engajamento comum em questões como a rejeição do aborto e a defesa da oração nas escolas.

No âmbito religioso, os anos setenta-oitenta são marcados por uma reconstrução do fundamentalismo, com fundação de novas congregações independentes. Os pontos essenciais do fundamentalismo das origens, no entanto, continuaram e permanecem ainda hoje, particularmente no que concerne à doutrina da inerrância da Escritura e à rejeição dos métodos científicos de investigação bíblica. Como no passado, grande parte dos fundamentalistas aceita como válida exclusivamente a tradução de King James.

\section{Sistematização e primeira análise dos principais elementos}

O fundamentalismo rejeita o modernismo e sua visão de religião, concretizada no liberalismo teológico (bíblico), cujos pontos centrais são ${ }^{13}$ :

- a pressuposição de que a religião deve adaptar-se aos novos tempos, à nova mentalidade forjada pelo iluminismo racionalista e pelos progressos das ciências naturais e da história;

\footnotetext{
${ }^{12}$ M. Corner, "Fundamentalism", in R.J. Coggins - J.L. Houlden (ed.), A Dictionary of Biblical Interpretation, London, 1990, 243-247, aqui 245-246.

${ }^{13}$ Cf. Roger Aubert, "Modernismo", in K. Rahner (coord.), Sacramentum Mundi, 4, Herder, 1973, 765-774.
} 
- diante da pluralidade de visões que estes novos dados implicam, nenhuma religião pode pretender exclusividade;

- como conseqüencia, os sistemas religiosos devem ser tolerantes, aceitando e assumindo os progressos atuais e abrindo espaço para outras crenças ou para o agnosticismo e o ateísmo;

- a tolerância tem como conseqüência uma menor exigência doutrinal e moral (que traz em si a tendência ao relativismo);

- na perspectiva da leitura bíblica, não considera seu caráter sobrenatural e inspirado, mas a tem como simples documento cujo teor é determinado por uma história e cultura precisas; deixa de lado também qualquer relação da Escritura com a tradição eclesial (sejam as verdades doutrinárias tradicionais das igrejas oriundas da reforma, seja a Tradição viva, no caso da Igreja Católica);

- a leitura bíblica deve ser feita unicamente por um acurado trabalho de investigação histórica e filológica (o chamado método histórico-crítico);

- na perspectiva teológica, acentuou a experiência interna da fé em detrimento de um conteúdo objetivo da mesma. Chegou assim à tese da incapacidade real de uma formulação de fé expressar a realidade de seu objeto (Deus), não podendo, portanto, veicular um dado objetivo, do que decorre a concepção de um processo puramente humano da evolução do dogma, inclusive desligado da mensagem e da pessoa de Jesus Cristo.

Como reação a esta visão das coisas, o fundamentalismo caracteriza-se pelos seguintes elementos centrais:

- afirmação do caráter absoluto da verdade religiosa tematizada pelo grupo e sintetizada em pontos fundamentais, em oposição ao saber cientifico e a qualquer forma de questionamento, ou, nas modalidades concordistas, em busca de uma legitimação da verdade bíblica pelas descobertas científicas. Em última instância, está implicada a afirmação de uma autoridade absoluta, apresentada como sendo o texto sagrado.

- a centralização da fé em formas consideradas originais, com claro interesse pela volta ao ponto de início (os dados fundamentais da fé). Distingue-se dos chamados conservadores, tradicionalistas ou ortodoxos na medida em que estes aceitam o desenvolvimento do sistema religioso, embora o detenham num determinado ponto do passado mais próximo ou mais remoto, enquanto que os fundamentalistas não aceitam tal desenvolvimento, mas fixam-se no que é considerado primordial.

- a pretensão de exclusividade, que traz consigo o radicalismo de posições (doutrinárias e morais), com a consequente intolerância religiosa.

- a nítida separação diante dos grupos que pensam diferentemente. Partindo de uma visão dualista (o mundo e a história divididos entre bons e 
maus, fiéis e infiéis), cultivam o separatismo em diversos graus, o qual conduz, por vezes, a uma militância agressiva. É neste contexto que muitos fundamentalistas cristãos rejeitam o diálogo ecumênico e o Conselho Mundial das Igrejas e realizam um trabalho missionário que não só pretende expandir suas convicções mas também anular, através de um trabalho destrutivo formalmente estabelecido, as crenças que dele diferem.

Dentro desta moldura, alguns pontos se destacam nos princípios fundamentalistas: os pontos fundamentais; a Bíblia; a comunidade de fé; a visão de mundo.

\subsection{Os pontos fundamentais}

Das cinco doutrinas fundamentais comumente aceitas, somente uma, a da inerrância da Escritura, tem cunho estritamente exegético. As outras são de âmbito dogmático:

- a concepção virginal defende a divindade de Jesus, com tudo o que daí decorre (seu poder sobre o mal, seu poder de realizar milagres). Opõe-se, assim ao racionalismo que apresentava Jesus como simples homem endeusado pelos discípulos e que rejeitava seus milagres, interpretando-os como poder natural sobre algumas realidades ou como fruto de um desconhecimento dos evangelistas acerca de certas condições da natureza;

- a expiação vicária de Jesus Cristo apresenta-o com único redentor que, expiando a pecaminosidade humana, é capaz de oferecer a salvação. Esta doutrina baseia a necessidade da aceitação pessoal de Jesus e da consequente conversão;

- a ressurreição de Cristo atesta sua messianidade e sua identidade como Filho de Deus. Opõe-se à negação ou explicação natural ou existencial da ressurreição pelo liberalismo. Está intimamente ligada à ressurreição dos fiéis, descrita normalmente, com base em 1Ts 4,14-18, como um arrebatamento físico aos céus;

- a volta gloriosa de Cristo para o julgamento, que orienta a vida segundo normas rígidas de moral, sobretudo contra o hedonismo.

\subsection{A Escritura}

A base da doutrina fundamentalista está numa determinada concepção do que seja a Escritura e de como o crente deve dela se aproximar. O ponto central consiste na chamada "inerrância" da Bíblia e na sua inspiração verbal. 
A inerrância se aplica a qualquer campo de conhecimento (doutrinal, moral, científico). Assim se expressa Falwell ${ }^{14}$ :

"Cremos na absoluta inerrância dos manuscritos hebraicos e gregos da Bíblia, baseados no seguinte silogismo. Premissa maior: a Bíblia declara ser palavra de Deus verbalmente inspirada (2Tm 3,16; Dt 8,3; Mt 4,4; 1Cor 2,13; 1Pd 1,21). Premissa menor: Deus não pode mentir (Nm 23,19; Tt 1,2). Conclusão: as palavras da Bíblia são todas verdadeiras (S1 119,43; Jo 17,17; 2Cor 6,7; Ef 1,13; $2 \mathrm{Tm} 2,15 ; \mathrm{Tg} 1,18)$. A Bíblia está isenta de erro em tudo o que afirma, quer se trate de afirmações sobre história, geografia e ciência, ou de afirmações teológicas."

A inerrância supõe a inspiração literal, no sentido de inspiração palavra por palavra, que beira à teoria do ditado. Afirma McIntire ${ }^{15}$ :

"A Bíblia é a palavra de Deus porque sua inspiração estende-se exclusivamente à escolha da palavra exata usada pelo autor para transmitir a mensagem de Deus ao homem."

Do princípio da inerrância e da inspiração literal derivam duas posturas diversas: de um lado, o literalismo na leitura da Bíblia; de outro, a rejeição de uma leitura literalista quando esta parece ensinar algo que contraria as doutrinas fundamentalistas. A explicação fundamentalista neste particular apela para uma distinção de formas verbais: verbos no indicativo devem ser lidos literalmente, enquanto que no imperativo devem ser interpretados espiritualmente $^{16}$. Desenvolve-se fortemente a tendência a fixar-se nos textos bíblicos que imediatamente (literalmente) demonstram a doutrina que se quer defender. Assim, textos vistos como puramente espirituais, sem relação direta com dados culturais, históricos, científicos, são normalmente deixados de lado em favor daqueles que podem ser usados na apologia da inerrância da Escritura (como são os textos de ações milagrosas ou extraordinárias). Uma

14 J. Falwell, "Carta a Foley", citado a partir de F. Galindo, O fenômeno das seitas fundamentalistas, 284.

${ }^{15}$ C. McIntire, "Twelve Reason Why the Bible is the Word of God", citado a partir de F. Galindo, O fenomeno das seitas fundamentalistas, 286.

${ }^{16}$ É assim que se rejeita uma leitura literalista, por exemplo, de textos como Mc 9,43-46 (arrancar o olho, a mão, o pé) e Mc 10,21 (vender tudo o que se tem e dar aos pobres, para ter um tesouro no céu). Exemplos e argumentação segundo F. Galindo, O fenômeno das seitas fundamentalistas, 288-289. 
leitura fundamentalista radical vai usá-los para defender a historicidade de tais eventos, enquanto que uma leitura fundamentalista concordista procurará explicar cientificamente estes mesmos eventos.

\subsection{A comunidade de fé}

O fundamentalismo tem origem a partir da pressuposição de que as igrejas tradicionais não deram uma resposta adequada às ideologias relativas aos avanços da época moderna, ou mesmo aceitaram tais ideias, traindo a fé. Daí a importância de constituir um grupo coeso alternativo às facções "apóstatas", que ofereça ao crente a certeza da verdade, conduzindo-o pouco a pouco em seu processo de conversão e adesão radical e incondicional.

\subsection{A visão de mundo}

A doutrina fundamentalista está intrinsecamente ligada a uma precisa visão de mundo, cujos pontos básicos são o dualismo e a escatologia iminente.

Partindo do antagonismo entre fé e modernidade, o fundamentalismo é marcadamente dualista: o "mundo" é o âmbito da ação do demônio e está destinado à perdição eterna; a comunidade dos crentes é o lugar onde Deus exerce seu domínio e leva à salvação. Este dualismo expressa-se em três âmbitos:

- como oposição entre duas formas de vida: o ser humano é colocado diante de uma opção pelo bem ou o mal, dois caminhos que levarão a desfechos opostos;

- como oposição entre a vida atual, terrena, de lutas e sofrimentos, e a vida eterna, feliz e plena. A vida terrena é então (de forma errônea) relativizada frente à vida eterna e as realidades puramente humanas perdem seu valor próprio, uma vez que o único ponto de interesse é a salvação escatológica;

- como oposição entre convertidos, crentes, de um lado, e pecadores, de outro, a qual conduz a um radical separatismo.

Estreitamente ligada ao dualismo está a visão escatológica fundamentalista, que deriva da interpretação literalista dos escritos apocalípticos bíblicos. Seguindo o dispensacionalismo, afirma a iminente a consumação de tudo. Deus rege a história por um desígnio a nós desconhecido mas inexorável, dentro de seu plano de predestinação. Sendo tudo o que ocorre uma fatalidade, o agir humano na história perde em significado. 


\section{Aprofundamento das principais questões envolvidas}

A partir dos dados levantados, a problemática do fundamentalismo gira em torno de algumas questões básicas que exigem aprofundamento: o problema da inerrância da Escritura e seu correlato, a conceituação e compreensão do processo da inspiração bíblica; a temática da comunidade de fé e sua relação com a Escritura (e, consequentemente, com a Teologia), com o que isto implica e pressupõe quanto ao conceito de Igreja; a questão da relação entre fé e razão ou, sob outro prisma, entre fé e cultura.

\subsection{A veracidade da Sagrada Escritura}

As dificuldades de compreensão da Sagrada Escritura são conhecidas já de longa data, no interior do judaísmo e na comunidade cristã primitiva. Diziam respeito, nessa época, às discordâncias ao menos aparentes entre textos. A patrística procurou ultrapassar o problema através da leitura espiritual, com o uso da tipologia e da alegoria, o que continuou na Idade Média. A questão não ocupava o primeiro plano, uma vez que o interesse primário voltava-se para o sentido religioso dos textos e sua relevância para a fé e a vida cristã. $\mathrm{Na}$ idade moderna, com o maior progresso nas ciências e o abandono paulatino de uma leitura espiritual, e particularmente com as novas teorias da ciência natural e os ganhos da história ocorridos no século XIX, a questão se levantou em todo o seu vigor.

Diversas foram as tentativas de solução, mas a tendência mais marcante foi a de considerar inerrantes os conteúdos de fé e moral ${ }^{17}$. Tal interpretação foi, porém, rejeitada pela Encíclica Providentissimus Deus, de Leão XIII, 1893:

"A possibilidade de erro está tão distante da inspiração divina que não só exclui qualquer erro, mas o exclui e o repele tão necessariamente como é necessário que Deus, a Verdade suprema, não pode ser causa de qualquer erro. É essa a fé antiga e constante da Igreja ... Daí, pensar que em passagens autênticas da Escritura Sagrada possa ocorrer algo de falso, ou é perverter o conceito católico da inspiração, ou transformar o próprio Deus em causador do erro" ${ }^{\prime 18}$.

\footnotetext{
7 Assim particularmente Maurice D’Hulst (cf. V. Mannucci, Biblia, Palavra de Deus, São Paulo, 1986, 281-282).

${ }_{18}$ Enchiridion Biblicum. Documenti della Chiesa sulla Sacra Scrittura. Edizione bilingue, Bologna, 1993 (indicado a partir de agora como $E B$ ), 124.126.
} 
O mesmo pensamento é repetido nas encíclicas Pascendi (Pio X, 1907), Spiritus Paraclitus (Bento XV, 1920) e Divino Afflante Spiritu (Pio XII, 1943). Passo decisivo foi dado por esta última, ao chamar a atenção para a necessidade de se considerar os gêneros literários:

\begin{abstract}
"Quando alguns presumem lançar em rosto dos autores sagrados ou algum erro histórico ou inexatidão ao relatar os fatos, vendo as coisas bem de perto, verifica-se que se trata simplesmente daqueles modos usuais e nativos de dizer ou de narrar que os antigos costumavam usar na mútua troca das ideias na convivência humana, e que realmente se usavam licitamente por tradição comum"19.
\end{abstract}

A Constituição Dei Verbum (n. 11-12) retoma estes ensinamentos:

"Como tudo o que os autores inspirados, isto é, os hagiógrafos afirmam (asserunt) deve ser considerado como afirmado (assertum) pelo Espírito Santo, por isso mesmo se deve acreditar que os Livros da Escritura ensinam com certeza, fielmente e sem erro a verdade que Deus, para nossa salvação (nostrae salutis causa), quis que fosse consignada nas sagradas Letras" ( $D V 11)$.

A primeira asserção enuncia que é verdadeiro, sem erro, aquilo que o autor inspirado afirma. A verdade da Escritura consiste na isenção de falsidade naquilo que é afirmado, ou seja, o que ela realmente quer ensinar. P. Benoit ${ }^{20}$ aponta três elementos a serem considerados para se identificar o que se quer realmente ensinar:

- o objeto formal, ou seja, o ponto de vista de quem fala: fala como historiador, como cientista, como filósofo, como poeta, como mestre na fé...?

- o grau de afirmação: em que medida a afirmação é ou não feita, como ela é apresentada: como algo categórico, como uma possibilidade ou probabilidade, como uma opinião.

- o modo como é proposto o conteúdo: se é uma parábola, uma alegoria, uma fábula, um relato moralizante, ou um relato histórico...

O texto da DV 11 aponta para o primeiro elemento, ao falar da "verdade que Deus, para nossa salvação, quis que fosse consignada". O objeto formal dos textos bíblicos, sua finalidade, é a salvação do gênero humano. Isto não

${ }^{19}$ EB 560 .

${ }^{20}$ Cf. "L'Inspiration", in Initiation biblique, Paris, 1954, 35ss. 
significa que só os ensinamentos doutrinais ou morais seriam sem erro, o que, aliás, até mesmo poderia ser questionado, já que no Antigo Testamento há doutrinas e comportamentos que foram superados pelo Novo Testamento. Mas, em todos e cada um dos textos importa analisar o escopo com o qual se escreveu. Esta é a luz através da qual se pode entender melhor a verdade absoluta da Escritura, pois esta é a perspectiva a partir da qual foram escritos os textos bíblicos.

Como consequência, os textos "ensinam com certeza, fielmente e sem erro", o que elimina a possibilidade de dúvida (certeza) e a deturpação da mensagem (fielmente) e atesta a verdade (sem erro). Em virtude da inspiração, a Sagrada Escritura é sempre veraz.

A questão se volta, então, para como saber o que um texto afirma, isto é, ensina. Assim se expressa a DV 12:

"Como Deus na Sagrada Escritura falou por meio dos homens e à maneira humana, o intérprete da Sagrada Escritura, para saber o que ele quis comunicar-nos, deve investigar com atenção o que os hagiógrafos realmente quiseram significar e que aprouve a Deus manifestar por meio das suas palavras ( $D V$ 12.1).

Para descobrir a intenção dos hagiógrafos, devem ser tidos também em conta, entre outras coisas, os gêneros literários. (...) Importa, por isso, que o intérprete busque o sentido que o hagiógrafo em determinadas circunstâncias, segundo as condições do seu tempo e da sua cultura, pretendeu exprimir e de fato exprimiu com a ajuda dos gêneros literários então em uso. Com efeito, para entender retamente o que o autor sagrado quis afirmar, deve atenderse convenientemente quer aos modos nativos de sentir, dizer ou narrar em uso nos tempos do hagiógrafo, quer àqueles que costumavam empregar-se nas relações entre os homens de então" ( $D V$ 12.2).

É a identificação do gênero literário que permite determinar o que um texto quer afirmar, isto é, a realidade que ele quer exprimir. A perspectiva de quem fala, o grau de afirmação, o modo como é proposto o conteúdo, são determinados pelo estudo do gênero literário.

Os dois parágrafos da Dei Verbum (11-12) indicam os elementos essenciais para a compreensão da veracidade da Escritura (veracidade como termo mais positivo e amplo do que inerrância). Se são consideradas atenta e adequadamente as condições culturais da produção de um texto, das quais faz parte o modo de expressão, entende-se que a Escritura ensine, em todas as suas 
passagens, a verdade da salvação "com certeza, fielmente e sem erro". Assim, não há nenhum erro formal também em matéria científica, histórica, geográfica... Os autores usaram os conhecimentos de seu tempo e seu próprio gênio, sem, porém, pretenderem ensinar ciências naturais, arqueologia, história ou geografia. Empregaram os elementos de sua cultura para expressar uma verdade salvífica, cujo autor último é Deus e que tem por finalidade expressar algo sobre Deus, o ser humano e o plano de Deus para este ${ }^{21}$.

Quanto às questões doutrinais e morais, pode-se afirmar também - e isto vale particularmente para o Antigo Testamento - não haver nenhum erro formal. Neste caso, deve-se considerar, além dos dados culturais, o arco maior que é a Revelação de Deus, que se desfralda num longo período de tempo, num movimento que vai do incipiente ao pleno. Nesse caso, é a totalidade da revelação, que só pode ser reconhecida se se tem em consideração a totalidade da Escritura (em sua relação também com a Tradição viva), que pode orientar a compreensão (cf. $D V 12.3)^{22}$.

A partir desses dados, compreende-se melhor os pressupostos da visão fundamentalista acerca da veracidade da Escritura.

Primeiramente, ela não sai do paradigma de compreensão da verdade no século XIX (verdadeiro seria somente o que pode ser comprovado pelos dados empíricos: documentos, testemunhas, resquícios arqueológicos) ${ }^{23}$, pois procura demonstrar que a Bíblia serve como fonte de história, ciência etc.

Em segundo lugar, os fundamentalistas não distinguem a palavra de Deus do texto que intermedeia esta palavra, pois não consideram a linguagem e as formas literárias utilizadas nas formulações dos textos originais ${ }^{24}$. Ao identificarem os dois, os fundamentalistas percebem todo questionamento de inerrância como questionamento do próprio Deus ${ }^{25}$.

Em terceiro lugar, ao predeterminar os princípios doutrinais irrenunciáveis e selecionar os textos significativos, embora apoiando-se no princípio da sola scriptura, na prática eliminam este princípio, pois se baseiam numa ideologia externa à Escritura ${ }^{26}$. E deixam sem explicação por que, se a

\footnotetext{
${ }^{21}$ DV 2: "aprouve a Deus... revelar-se a si mesmo e dar a conhecer o mistério da sua vontade".

${ }^{22}$ Assim, por exemplo, a superação da doutrina do sheol e doutrina da retribuição nesta vida pela da ressurreição e da escatologia diversificada para justos e injustos, bem como certas narrações de crueldade que atribuem a Deus a causalidade última dos fatos.

${ }^{23}$ Cf. M. Corner, "Fundamentalism", in R.J. Coggins - J.L. Houlden (ed.), A Dictionary of Biblical Interpretation, London, 1990, 243-247, aqui 244.

${ }^{24}$ Cf. Pontifícia Comissão Bíblica, A Interpretação da Bíblia na Igreja (1993), I, F (EB 13841386).

${ }^{25}$ Cf. M. Corner, "Fundamentalism", 244-245.

${ }^{26} \mathrm{Cf}$. A Interpretação da Bíblia na Igreja, I, F (EB 1383. 1389).
} 
compreensão dos textos é feita pela inspiração pessoal do Espírito, há tantas diferenças entre os próprios grupos fundamentalistas quanto à interpretação de certas passagens. Na realidade, como bem observa $\mathrm{M}$. $\mathrm{Corner}^{27}$, não se dão conta da questão hermenêutica envolvida em toda leitura bíblica. De um lado, parece ser suficiente aceitar a autoridade da Bíblia, sem uma ulterior pergunta acerca de sua compreensão e sua aplicação ao tempo atual. De outro lado, a leitura bíblica parece reduzir-se a uma recepção simples e passiva do que a Bíblia traz escrito, sem ter em conta o que as modernas tendências hermenêuticas apresentam sobre o papel ativo do leitor: a noção de "fusão de dois horizontes" (do leitor e do texto), posto por Gadamer, e a importância da apropriação do texto pelos leitores de uma nova época, sem o que o trabalho interpretativo não chegou a seu término, segundo Ricouer ${ }^{28}$. Também nesse ponto liberalismo e fundamentalismo se encontram: ambos apresentam o texto bíblico como uma entidade $a$ se que se impõe ao leitor, sem dar suficiente atenção ao papel deste na interpretação.

\subsection{A inspiração}

A insistência inadequada na comprovação da historicidade dos relatos e de sua concordância, mesmo nos detalhes, com os dados atuais das diversas ciências, está ligada, no fundamentalismo, à não consideração dos gêneros literários e dos modos de expressão de uma língua, uma cultura e momentos históricos bastante distantes no tempo e no espaço ${ }^{29}$. Com isto, identifica-se, em última instância, Palavra de Deus e palavras humanas. A Dei Verbum acena discretamente para tal distinção no capítulo em que trata da inspiração e da interpretação da Escritura. Diz, com efeito, em 12.1:

"o intérprete da Sagrada Escritura, para saber o que ele [Deus] quis comunicar-nos, deve investigar com atenção o que os hagiógrafos realmente quiseram significar e que aprouve a Deus manifestar por meio das suas palavras."

Não há uma simples paridade entre "o que os hagiógrafos quiseram significar" e "o que aprouve a Deus manifestar por suas palavras". Uma coisa não é simplesmente a outra. O "e" adiciona um elemento ao outro, distinguindo-os, embora como duas faces de uma única realidade, o texto inspirado. Enquanto as palavras humanas são condicionadas pelo tempo, pela

\footnotetext{
${ }^{27}$ Cf. M. Corner, "Fundamentalism", 245.

${ }^{28} \mathrm{Cf}$. A Interpretação da Bíblia na Igreja, I, F (EB 1394-1395).

${ }^{29} \mathrm{Cf}$. A Interpretação da Bíblia na Igreja, I, F (EB 1384).
} 
situação dos autores, pelas possibilidades das línguas em que foi escrita a Bíblia, a Palavra de Deus ultrapassa o texto, embora dele se sirva como instrumento de expressão. Por outro lado, é através da investigação do que os "hagiógrafos quiseram significar" (o que supõe a materialidade do texto) que se chega aos que Deus "quis comunicar-nos ... por meio de suas palavras".

Para esclarecer o processo da manifestação da Palavra de Deus em palavras humanas, a encíclica Providentissimus Deus insiste na ação do Espírito nas três fases que dão origem ao texto: na compreensão do autor acerca da mensagem a ser transmitida, na sua deliberação para escrever tal compreensão e, por fim, em sua forma de expressão durante seu trabalho de pôr por escrito a mensagem. Isto não implica, porém, a concepção de um ditado do texto, pois enfatiza-se a liberdade do ser humano. A Divino Afflante Spiritu deixa claro este aspecto:

"Partindo do fato de que o hagiógrafo, na composição do livro sagrado, é o organon ou o instrumento do Espírito Santo, mas instrumento vivo e dotado de razão, fazem observar precisamente que este instrumento, impelido pela moção divina, usa de tal forma as suas faculdades e as suas forças que todos facilmente podem verificar, pelo livro, a índole própria de cada um, suas orientações e suas singulares características" ( $E B$ 556).

Em outras palavras, o fato de o hagiógrafo deixar suas marcas no texto torna palpável o dado de que ele é realmente ativo e não um instrumento passivo, como seria o caso da inspiração por ditado verbal. Nesse caso, com efeito, seria de se supor uma uniformidade de linguagem em todos os escritos bíblicos. Expressa-se, com essa concepção dinâmica do processo da inspiração, de modo particular, a colaboração entre Deus e o homem, entre graça e liberdade. Aflora com evidência a natureza histórica da revelação bíblica, em que se articulam agir humano e agir divino. Embora Deus seja o Senhor da história e da revelação, este fato, longe de anular a colaboração humana, abre a esta novas e inusitadas possibilidades. Enfim, aflora aqui a dinâmica "encarnatória" da revelação, qual sua lógica intrínseca e que tem em Cristo, a Palavra de Deus encarnada, cabeça de tudo (cf. Ef 1,10), seu exemplar e sua meta últimos. É nesse sentido que o Documento $A$ Interpretação da Bíblia na Igreja, da Pontifícia Comissão Bíblica, chama a atenção para o fato que o fundamentalismo é "incapaz de aceitar a verdade da própria encarnação" ${ }^{30}$.

${ }^{30} \mathrm{Cf}$. A Interpretação da Bíblia na Igreja, I, F (EB 1384). 


\subsection{A comunidade de fé e sua relação com a Escritura}

O fenômeno do fundamentalismo põe em realce a importância de uma correta impostação da relação entre Escritura e Tradição, que é exigida formalmente pela teologia católica mas que tem lugar também, a seu modo, nas igrejas oriundas da reforma. Ambas tematizam o fato que a Escritura, por sua importância como documento escrito (uma vez que fixa uma tradição anterior), tem uma relativa primazia frente à Tradição ${ }^{31}$. Mas exatamente uma primazia relativa, pois foi a Tradição que deu origem à Escritura, que a reconheceu e reconhece como sagrada e que faz a letra (ligada necessariamente ao passado) tornar-se palavra viva para as comunidades crentes. Mais particularmente, é a Tradição que orienta a interpretação da Escritura $^{32}$.

A postura fundamentalista não se dá conta que falar de inerrância da Bíblia só tem sentido se é envolvido o leitor, ou seja, se a interpretação do texto puder ser "inerrante" inerrante se não há uma instância interpretativa com autoridade que vá além da subjetividade de um líder. Na Igreja Católica, tal papel é desempenhado pelo Magistério, levando em conta a inter-relação entre Escritura e Tradição viva. Nas igrejas protestantes há instâncias normativas com formulações que orientam a interpretação para além de uma decisão individual. Também o fundamentalismo tem uma regra de fé, tematizada nos cinco artigos fundamentais, e a normatividade do pensamento de um líder, marcado fortemente, porém, por suas opções (mesmo se religiosas). Ou seja, na realidade, diferentemente do que pregam, no fundamentalismo não é a Escritura que dita o que deve ser a fé e como se deve constituir a comunidade, mas é a comunidade que dita o sentido da Escritura. Na origem do

\footnotetext{
${ }^{31}$ Na medida em que ela garante a origem divino-apostólica de uma verdade da Tradição. Cf. P. Langsfeld, "Tradição e Sagrada Escritura - sua relação mútua", in J. Feiner - M. Löhrer, Mysterium Salutis, I/2, Petrópolis, 1971, 241-242. O autor chama a atenção, no entanto, que esta primazia relativa só pode ser conhecida através da Tradição, de modo que Escritura e Tradição são totalmente inderdependentes (cf. op.cit., p. 239-240).

${ }^{32} \mathrm{Um}$ exemplo pode demonstrar esta asserção. A fé cristã no Deus uno e trino encontra-se atestada na Escritura. No entanto, considerado a partir só da Escritura, este dado de fé poderia ser compreendido de diversas maneiras (como subordinacianismo, modalismo etc). O que orienta a leitura de fé não é só a aproximação de textos e sua mútua complementação (por exemplo: "eu e o Pai somos um", Jo 10,30, que afirma a igualdade; e "daquele dia e daquela hora, ninguém sabe, nem os anjos no céu, nem o Filho, somente o Pai", Mc 13,32, que afirma a desigualdade), mas também a ponderação oriunda da compreensão de fé divino-apostólica no interior da comunidade crente. Esta última é que dá o peso a cada um dos testemunhos e, portanto, orienta a compreensão.

${ }^{33}$ Cf. M. Corner, "Fundamentalism”, 245.
} 
fundamentalismo não está o dado bíblico, mas uma doutrina bem definida e um determinado modo de concebê-la, que levam à seleção de textos que interessem à comprovação de suas mesmas ideias.

Nesse sentido, o problema do fundamentalismo não é propriamente ter pontos fixos de fé, mas o fato de se tratar de uma fixação de dogmas que dirigem a leitura, de modo a prescindir do crescimento da compreensão da Escritura, que vem pela Tradição viva.

A partir destes elementos, verifica-se que tanto no fundamentalismo como fora dele há uma íntima relação entre comunidade de fé e Escritura, porém tematizada de modo completamente diverso. A questão não é ter verdades fundamentais. Isto já ocorrera nas igrejas da reforma ${ }^{34}$ e, na igreja Católica foi delineado ultimamente na expressão "hierarquia das verdades" 35 . A questão é a rejeição teórica e prática, no fundamentalismo, da Tradição viva $^{36}$. Esta, segundo a concepção católica ${ }^{37}$, não se restringe ao Magistério embora ele tenha nela um papel de discernimento autorizado assistido pelo Espírito Santo (cf. $D V 8.2 ; 10,2.3$ ) -, mas abarca toda a Igreja: a reflexão, os estudo, a penetração espiritual de todos os fieis - incluindo aqui os teólogos e exegetas (cf. $D V$ 8.2). Tal posicionamento implica um crescimento e progresso da Tradição (cf. $D V$ 8.2), que conta também com os instrumentos das ciências humanas (história, arqueologia, geografia, filologia...), leva em consideração os ganhos das ciências naturais e o desenvolvimento das teorias literárias e hermenêuticas. Não se opõe, assim, nem aos progressos humanos nem às exigências dos métodos científicos de investigação do texto, mas oferece o horizonte para sua utilização.

\footnotetext{
${ }^{34}$ Cf. No final do século XVI e início do XVII surge, entre os reformados, a diferenciação entre artigos fundamentais e não fundamentais para a fé e a salvação. A igreja seria o conjunto das comunidades cristãs em seu acordo nas proposições fundamentais. No século XVII formulam-se os artigos fundamentais, que seriam verdades de fé professadas nos cinco primeiros séculos da Igreja. A ortodoxia luterana assumiu esta diferenciação (por exemplo A. Calov). Com o tempo, a finalidade da indicação de pontos fundamentais passou de demarcar as fronteiras entre as diversas confissões cristãs para a de realçar os pontos comuns básicos da fé cristã. A Igreja Católica rejeitou esta diferenciação. Cf. K. Algermissen, "Fundamentalartikel", in K. Rahner (ed.), Lexikon für Theologie und Kirche (2 ${ }^{\mathrm{a}}$. ed.), 4, Freiburg, 1960, 450-451.

${ }^{35} \mathrm{Cf}$. Concílio Vaticano II, Unitatis Redintegratio, 11.3.

${ }^{36} \mathrm{Cf}$. A Interpretação da Bíblia na Igreja, I, F, (EB 1389).

${ }^{37} \mathrm{Na}$ concepção católica, a Tradição abarca não só a doutrina e moral, mas o culto, a própria vida da Igreja, que, tendo origem divino-apostólica, perpetua-se na história e, na Igreja, é transmitido como garantia de sua identidade e de sua fé e vivência (cf. $D V$ 8.1). É, portanto, algo vivo, dinâmico, que não pára no passado, mas que une diacronicamente a Igreja dos primórdios à Igreja de todas as épocas. Nela a Igreja se reconhece e dela vive constantemente. A Igreja a aplica e com ela - intimamente ligada à Escritura - procura compreender sempre mais a Revelação, de modo a afrontar os desafios de cada etapa histórica.
} 
Implícito em tal impostação está um determinado conceito de igreja, que, na realidade, se contrapõe às comunidades, forjando uma maneira "privada" de interpretar a Escritura. Assim se expressa o documento $A$ Interpretação da Bíblia na Igreja: ${ }^{38}$

“em adesão ao princípio da 'sola Scriptura', o
fundamentalismo separa a interpretação da Bíblia da
Tradição guiada pelo Espírito, que se desenvolve
autenticamente em ligação com a Escritura no seio da
comunidade de fé. Falta-lhe entender que o Novo
Testamento tomou forma no interior da Igreja cristã e que
ele é Escritura Santa desta Igreja, cuja existência precedeu
a composição de seus textos. Assim, o fundamentalismo é
muitas vezes anti-eclesial; ele considera negligenciáveis os
credos, os dogmas e as práticas litúrgicas que se tornaram
parte da tradição eclesiástica, como também a função de
ensinamento da própria Igreja. Ele se apresenta como uma
forma de interpretação privada, que não reconhece que a
Igreja é fundada sobre a Bíblia e tira sua vida e sua
inspiração das Escrituras."

\subsection{A relação entre fé e razão}

Caracteriza-se o fundamentalismo moderno como reação não somente contra os ganhos da ciência, mas contra sua pretensão de julgar as assertivas doutrinais e, particularmente, a validade dos dados bíblicos. Exalta, nesse sentido, a fé, em detrimento da razão, que vem aniquilada formal (nas formas que rejeitam em bloco os dados científicos) ou implicitamente (nas formas que, pelo concordismo, relacionam de forma defeituosa ciência e fé). Tal postura encontra sua explicação imediata na situação considerada caótica à qual se procurou responder criando um ambiente seguro onde tem a primazia a certeza da fé. A finalidade do fundamentalismo é, ao propor doutrinas inquestionáveis, levar a uma certeza tal que supere a crise criada pelo modernismo ${ }^{39}$. Embora suas raízes encontrem-se já em épocas remotas, o quadro no qual surgiu e se desenvolveu é, portanto, o da dicotomia entre fé e razão (e, nele incluído, entre fé e cultura), elevado a paradigma pelo modernismo, assim como a teologia e a exegese liberais.

\footnotetext{
${ }^{38}$ A Interpretação da Bíblia na Igreja, I, F (EB 1389).

${ }^{39}$ Cf. J. Wicks, "Fundamentalismo", in R. Latourelle - R. Fisichella, Dicionário de Teologia Fundamental, Petrópolis - Aparecida, 1994, 332.
} 
Até os primeiros séculos da Idade Média, a leitura e interpretação da Escritura desenvolvia-se no quadro unitário que integrava a reflexão humana na fé, concebida como regula fidei, isto é, como conjunto que define a doutrina cristã. $O$ desenvolvimento do dogma cristão, com sua expressão sempre mais tematizada em fórmulas indicativas, sobretudo a partir do confronto com as heresias dos primeiros séculos, conduziu paulatinamente, no entanto, a um afastamento entre o dado bíblico e o doutrinal. A leitura bíblica passou então a ser cultivada principalmente com escopo espiritualcontemplativo e místico ${ }^{40}$, que, pouco a pouco chegou a desligar regula fidei e espiritualidade. Levada ao extremo em alguns setores, a leitura espiritual tornou-se sempre mais marcada pela subjetividade, perdendo em grande parte a referência eclesial, chegando-se assim à separação entre o sentido bíblico e o espiritualista ${ }^{41}$. A importância do retorno à valorização do sentido bíblico (literal ${ }^{42}$ ) como base para a interpretação, dentro da linha da patrística, será enfatizada por Santo Tomás de Aquino ${ }^{43}$. Busca-se a reunificação entre fé e razão e a eliminação do subjetivismo. O pensamento de Santo Tomás marcará também os séculos posteriores e foi reafirmado de modo particular no século XVI, quando a teologia católica, frente às afirmações da reforma protestante, percebeu a necessidade de uma acurada reflexão propriamente bíblica para comprovação de sua doutrina.

A leitura bíblica dos primeiros tempos da reforma baseava-se em dois princípios: o da sola Scriptura e o da sola fides. Rejeitando-se uma regra de fé externa à própria Bíblia, segundo o princípio da sola Scriptura, reafirmou-se fortemente a importância da investigação do que seria o sentido próprio da Escritura (independente da fé da Igreja e, particularmente, do Magistério católico) e, nesse sentido, a razão. Pelo princípio da sola fides, que, sobre o pressuposto da corrupção substancial do ser humano, rejeita a analogia

\footnotetext{
${ }^{40}$ Cf. H. de Lubac, A Escritura na Tradição, São Paulo, 1970, 52-54.

${ }^{41}$ Cf. H. de Lubac, A Escritura na Tradição, 57-59. Fala-se aqui de sentido "espiritualista" para distinguir uma compreensão espiritualizante dos textos em termos subjetivos, que nada tem a ver com o sentido espiritual. Este é a legítima leitura dos textos à luz do mistério pascal, como contexto que os ilumina e reinterpreta. Cf. A Interpretação da Bíblia na Igreja (II, B, 2; EB 1412-1413.1416).

${ }^{42}$ Por sentido literal entende-se o sentido do texto considerada a sua situação de origem e seu gênero literário. Distingue-se o sentido "literalista", que, não levando em conta estes aspectos, apega-se a um significado palavra por palavra (cf. A Interpretação da Bíblia na Igreja, II, B, 2; $E B$ 1405-1406).

${ }^{43}$ Cf. S.Th. I, q. I, a. 1-3. Para Santo Tomás, sentido literal é aquele que advém imediatamente das palavras do texto; sentido espiritual (alegórico, moral e anagógico) são as realidades significadas pelas palavras. Cf. J.G. Prior, The Historical Critical Method in Catholic Exegesis, Roma, 1999, 53-55.
} 
rationis, afirma-se a fé desligada da razão ${ }^{44}$. Desenha-se, dessa maneira, um sistema que, se de um lado inclui fé e razão, embora como dois elementos separados, de outro, tematiza a fé em seu aspecto subjetivo, independente da regula fidei. Desaparece formalmente da leitura bíblica o quadro de referência eclesial.

Com o desenvolvimento científico que se consolidou nos séculos seguintes, abandonou-se a leitura espiritual da Escritura, apresentada sob a caricatura da leitura espiritualista de alguns setores medievais e em parte retomada também posteriormente ${ }^{45}$. O quadro referencial para a exegese passou a ser os ganhos das ciências naturais e sobretudo da história. $\mathrm{O}$ iluminismo levou, por fim, não só à tentativa de purificar o texto bíblico dos paradigmas da fé, como é característico dos estudos bíblicos do século XVII ${ }^{46}$, mas ainda à formal eliminação do elemento dogmático. $\mathrm{O}$ modelo para interpretação da Bíblia passou da regula fidei à "regula historiae". Restrito primeiramente ao âmbito protestante, atingiu aos poucos também exegetas católicos, embora aqui, em virtude das reservas manifestadas pelo Magistério, a penetração tenha sido, nestes séculos, em menores proporções.

Marcadamente racionalista e de cunho historicista, a leitura bíblica aplicou-se, nos séculos XVII-XIX, à investigação sobre os evangelhos (a chamada Leben-Jesu-Forschung). No século XIX, a "nova escola de Tübingen" ou "escola liberal" objetivou ao máximo o dado histórico, pretendendo analisá-lo com o método das ciências naturais. Fé e razão aparecem então não só como separadas, mas opostas. $\mathrm{O}$ mesmo ocorrerá com o pensamento de R. Bultmann, que, embora rejeitando o conceito positivista de história defendido pela escola liberal, fez florescer o racionalismo ligado à precompreensão existencialista da Escritura. Os esforços de grandes pensadores das igrejas protestantes da época, sobretudo de K. Barth (que demonstrou a relevância da consideração, ao lado da pesquisa histórica, do sentido teológico ${ }^{47}$ ), não conseguiram reconduzir ao equilíbrio.

Foi neste caminho, iniciado já no século XVI, que se constituíram pouco as pouco as diversas etapas do assim chamado método histórico-crítico, o qual surgiu, por conseguinte, estreitamente marcado pelo racionalismo e pelo historicismo.

\footnotetext{
${ }^{44}$ Cf. K. Lehmann, "El horizonte hermenéutico de la exégesis histórico-crítica", in J. Schreiner (ed.), Introducción a los Métodos de la Exégesis Bíblica, Barcelona, 1971, 65.

${ }^{45}$ Cf. H. de Lubac, A Escritura na Tradição, 62-65.

${ }^{46} \mathrm{Cf}$., por exemplo, a crítica do Pentateuco que se desenvolve neste tempo.

${ }^{47}$ K. Lehmann, "El horizonte hermenéutico de la exégesis histórico-crítica", 71-72; C.A. Baxter, "Barth, K.", in A Dictionary of Biblical Interpretation, 77-79.
} 
Este divórcio entre fé e razão, que se veio preparando desde a leitura espiritualizante da Idade Média e se concretizou particularmente na escola liberal, favoreceu o aparecimento das leituras simplistas de corte fundamentalista. É, no entanto, o fundamentalismo, uma justa e adequada resposta aos exageros do método histórico-crítico? Deve-se prescindir de seu uso para que se possa chegar a uma leitura que integre fé e razão? Vários elementos devem ser considerados nestas questões.

Atualmente, percebe-se a possibilidade de se distinguir entre o método histórico-crítico e os pressupostos ideológicos nos quais nasceu ${ }^{48} \mathrm{e}$ a necessidade de complementá-lo com metodologias de corte sincrônico (análise narrativa, retórica, semiótica) ${ }^{49}$. Pelo fato de a Escritura nos trazer textos antigos, uma abordagem de cunho diacrônico será sempre importante e necessária ${ }^{50}$ (ao menos nos aspectos essenciais) para se evitar uma leitura anacrônica. A sincronia, porém, tem primazia na medida em que o texto final é o objeto material da exegese.

Por outro lado, deve-se estar consciente dos limites da metodologia diacrônica. Por seu cunho marcadamente histórico, por si mesma ela não é capaz de dar conta do caráter inspirado da Escritura e, com isso, não visa diretamente apontar o significado cristológico e eclesial dos textos ${ }^{51}$. Por este motivo, para além de sua complementação com outras metodologias, é mister colocar o método histórico-crítico num quadro referencial diverso daquele no qual ainda hoje está, em geral, situado. Não basta sobrepor etapas, acrescentando à análise crítica, num segundo momento, a visão de fé. É mister enquadrar a crítica na moldura da fé, realizá-la tendo como pressuposto explícito o caráter inspirado dos textos bíblicos e a procura de, através do texto, encontrar a Palavra do Deus que se auto-comunica. A questão, por conseguinte, não é propriamente criar uma nova metodologia, mas impostar a metodologia (qualquer que ela seja) "no mesmo Espírito com que foi escrita" a Escritura ( $D V$ 12.3). Isto levará a uma utilização diversa dos ganhos metodológicos do método histórico-crítico (e das outras diversas metodologias). Nesse sentido, é algo novo, mas que sabe aproveitar os elementos positivos de uma leitura inicialmente contrária à fé.

\footnotetext{
${ }^{48}$ Cf. A Interpretação da Bíblia na Igreja, I, 4 (EB 1285). A Instrução Sancta Mater Ecclesia (sobre a historicidade dos evangelhos, 1964) já fizera a mesma avaliação acerca da Formgeschichte (cf. EB 647).

${ }^{49} \mathrm{Cf}$. A Interpretação da Bíblia na Igreja, I, 4 (EB 1289)

${ }^{50} \mathrm{Cf}$. O documento A Interpretação da Bíblia na Igreja apresenta-o (a par das reservas que lhe faz) como "indispensável” (I, A: EB 1275).

${ }^{51}$ Cf. Cf. A interpretação da Bíblia na Igreja, Conclusão (EB 1558).
} 
Como realizar tal escopo? Mesmo sem a pretensão de traçar um caminho pragmático, alguns princípios podem ser delineados.

Primeiramente, a face humana e a face divina da Escritura estão intimamente relacionadas. Como Deus se revelou na história através de acontecimentos e palavras intimamente conexos entre si (cf. $D V 2$ ), cujo ponto culminante é o próprio "historicizar-se" do Verbo de Deus, assim o humano e o divino na Escritura não podem ser dissociados. São distintos, mas inseparáveis. Como através das palavras humanas revela-se a Palavra de Deus, tem-se o acesso à Palavra de Deus somente através das palavras humanas, como também em Jesus Cristo a sua humanidade era caminho para a divindade. Por isso toda leitura "científica" deve ser igualmente "teológica".

Em segundo lugar, se o método de cada ciência define-se pelo objeto de estudo, é necessário determinar o real objeto de estudo da exegese. Ele inclui não somente a face humana da Escritura, as palavras em sua situação de origem, mas inclui a face divina, a Palavra de Deus que se expressa de modo humano, mas que transcende este modo de expressão. $\mathrm{O}$ exegeta pode realizar metodologicamente essa perspectiva através da colocação de sua análise no quadro referencial da fé eclesial, que deve preceder e acompanhar seu trabalho. Cai aqui o mito de (pseudo-)cientificidade das análises puramente históricas dos textos bíblicos, segundo as quais quanto mais "racional" e menos "crente" forem, mais justos serão seus resultados. Como não existe nenhum processo de conhecimento absolutamente neutro, é necessário colocar os pressupostos adequados à análise, que lhe dêem condição de possibilidade para uma compreensão o mais aderente possível à Palavra. Se a Escritura é um documento que nasceu da fé e visa gerar a fé, esta mesma fé não pode ser considerada um pressuposto ideológico incompatível com a análise, mas, antes, o pressuposto indispensável. Assim sendo, quanto maior a sintonia com o dado da fé, maior a possibilidade de uma compreensão da Escritura como Palavra de Deus em palavras humanas.

Em terceiro lugar, em virtude da unidade da Revelação - um só Deus que se auto-comunica, com um único desígnio salvífico, embora num desenvolvimento longo que inclui muitas manifestações -, a Escritura, embora testemunhando os diversos momentos desta auto-manifestação, possui uma unidade. Metodologicamente, isto exige que toda leitura bíblica esteja aberta para a totalidade da mensagem, para a globalidade da Escritura, que tem em Cristo sua chave hermenêutica (cf. $D V$ 12.3).

Em síntese, a colocação da análise crítica no contexto da fé não compromete a justa autonomia da razão, mas enquadra-a no horizonte adequado ao objeto de estudo e abre-a para a possibilidade de se tornar fecunda para a fé e a vida da Igreja. 
Depois da dicotomia criada no decorrer da história da interpretação cristã da Escritura, urge uma nova síntese, onde a consideração da fé não signifique uma imaginativa espiritualização nem um estagnado fundamentalismo. Este aparenta partir de uma fé objetiva (os cinco princípios fundamentais), mas, na realidade, processa-se dentro do subjetivismo. Em outras palavras, funciona (embora invertendo-a) dentro da mesma lógica que visa combater, a do racionalismo, na medida em que admite tacitamente a dicotomia entre fé e razão. Apresenta a fé como critério para a razão, mas uma fé sem referência eclesial e que não sabe se conjugar com a razão. Também no fundamentalismo de corte concordista esta é de fato a perspectiva, uma vez que a razão é utilizada somente como comprovação da fé e não em real e fecundo diálogo com ela. Ambas as visões são reducionistas, não percebem suficientemente a natureza e os próprios limites dos dados científicos e não concebem adequadamente a fé ${ }^{52}$.

\title{
Conclusão
}

Surgindo por uma motivação exclusivamente religiosa, o fundamentalismo tornou-se uma concepção de mundo, chegando a abarcar também dimensões políticas. Em virtude de seu ideário radical, adquiriu um sentido amplo, indicando uma concepção religiosa ou ideológica de cunho intolerante ou radicalista, com forte marca militante. Sociologicamente, existe hoje em pequenos grupos dentro de denominações religiosas e partidos políticos.

No que concerne à sua interpretação da Escritura cristã, o Documento $A$ Interpretação da Bíblia na Igreja reconhece alguns valores na leitura fundamentalista, ao valorizarem "a inspiração divina, a inerrância da Palavra de Deus e as outras verdades" $"$. Porém, de todas as leituras (métodos e abordagens) apresentadas por este documento e nele avaliadas, a leitura fundamentalista é a única que é rejeitada em bloco. Assim se expressa:

\begin{abstract}
“A abordagem fundamentalista é perigosa, pois ela é atraente para as pessoas que procuram respostas bíblicas para seus problemas da vida. Ela pode enganá-las, oferecendo-lhes interpretações piedosas mas ilusórias, ao invés de lhes dizer que a Bíblia não contém necessariamente uma resposta imediata a cada um desses problemas. O fundamentalismo convida, sem dizê-lo, a uma forma de suicídio do pensamento. Ele coloca na vida
\end{abstract}

\footnotetext{
${ }^{52}$ Cf. M. Corner, "Fundamentalism", 244.

${ }^{53} \mathrm{Cf}$. A Interpretação da Bíblia na Igreja, I, F (EB 1383).
} 
uma falsa certeza, pois confunde inconscientemente as limitações humanas da mensagem bíblica com a substância divina dessa mensagem." 54

Dois pontos aqui se destacam. Em primeiro lugar, esta leitura é perigosa pela força de atração que exerce ao apresentar (aparentes) soluções para os problemas quotidianos. $\mathrm{Na}$ realidade, contudo, não oferecem resposta nem segurança, pois não sabem ler a Escritura e dela depreender seu sentido próprio, do qual depende sua aplicação na vida.

Em segundo lugar, elimina a razão, substituindo-a pela rigidez de ideias inquestionáveis. Ao fixar-se em concepções científicas já superadas, ele torna impossível o diálogo entre fé e razão e entre fé e cultura ${ }^{55}$. O fundamentalismo deve ser questionado pela razão. Em toda religião há verdades que estão acima de qualquer discussão e são objeto de fé. Isto, porém, não significa que estejam acima de uma crítica que, considerando sua inteligibilidade, permita sua compreensão e aprofundamento. Assim sendo, o problema é que os princípios fundamentais entraram em seu sistema como algo absoluto, fechado ao entendimento. A falta de espaço que concede ao pensar humano, à possibilidade de investigação e aprofundamento das verdades apresentadas como fundamento fecha a porta a qualquer discurso razoável (segundo a razão) e, com isto, torna-se inaceitável. Em seu discurso na universidade de Regensburg, em 12 de setembro de 2006, o Papa Bento XVI chamou a atenção para o fato que a fé que não admite diálogo com a razão torna-se ameaçadora $^{56}$. É necessário admitir este diálogo, não para dissolver o tecido da fé, mas para entender a inteligibilidade da fé. Entre a revelação de Deus e o conhecimento humano há uma analogia, pois a revelação é exatamente dirigida ao ser humano (racional). Se há uma analogia, o que é proposta de fé tem uma relativa capacidade de ser entendido pela razão. Além disso, as verdades não podem ser simplesmente colocadas uma ao lado da outra, nem apresentadas todas como "básicas", mas deve-se perceber a orgânica hierarquia em que se encontram. Uma verdade é horizonte de inteligibilidade de outras verdades. Assim, por exemplo, o Deus encarnado é a razão da

\footnotetext{
${ }^{54}$ A Interpretação da Bíblia na Igreja, I, F (EB 1390).

${ }_{55} \mathrm{Cf}$. A Interpretação da Bíblia na Igreja, I, F (EB 1388).

56 “'(...) trata-se de um alargamento do nosso conceito de razão e do seu uso. Porque com toda a alegria diante das possibilidades do homem, vemos também as ameaças que sobressaem destas possibilidades e devemos perguntar-nos como podemos dominá-las. Só o conseguiremos se razão e fé estiverem unidas de uma nova forma; se superarmos a limitação autodecretada da razão ao que é verificável na experiência, e lhe abrirmos de novo toda a sua vastidão. (...) Só assim nos tornamos também capazes de um verdadeiro diálogo das culturas e das religiões um diálogo do qual temos urgente necessidade."
} 
inteligibilidade da Igreja como sacramento, como Corpo de Cristo. Por isso, pode ser cobrado exatamente por uma visão de fé que uma determinada asserção seja colocada dentro do conjunto, o que não é possível dentro do sistema fundamentalista.

Como enfrentar o fundamentalismo? Foi há algum tempo concluída uma pesquisa sobre a leitura da Bíblia entre adultos. Dirigida pelo sociólogo Luca Diotallevi, professor da Universidade de Roma Tre, a pesquisa foi desenvolvida considerando nove países (Estados Unidos, Grã-Bretanha, Holanda, Alemanha, França, Espanha, Itália, Polónia e Rússia europeia). Os primeiros resultados foram apresentados na Sala Stampa da Santa Sé em 29 de abril de $2008^{57}$. Dentre os mais importantes, três podem ser destacados: primeiramente, a Bíblia é considerada um texto de leitura difícil; em segundo lugar, ficou evidente que os fundamentalistas demonstraram um menor conhecimento da Escritura, enquanto os que a lêem criticamente demonstraram um maior conhecimento; em terceiro lugar, a leitura bíblica depende não do credo religioso, mas da ligação do indivíduo com grupos onde se pratica a leitura da Escritura. Estes três pontos abrem pistas importantes a nível pastoral:

- dada a dificuldade do texto da Escritura, é necessário que a leitura bíblica seja orientada, para que possa ser entendida e, então, atualizada;

- este entendimento não deve ficar só em nível intelectual (histórico, literário, filológico), mas deve ser permeável à vida do indivíduo e da comunidade de fé;

- fica sublinhado assim, de um lado, o papel da comunidade de fé como lugar para o cultivo da leitura bíblica e, de outro, a necessidade de uma grande atenção aos meios disponíveis para o cultivo da Palavra: a liturgia, a catequese, a oração comum.

Se o fundamentalismo vive da oposição entre fé e razão (cultura), para sua superação muito poderá contribuir uma prática (acadêmica e pastoral) da leitura bíblica que integre os ganhos da exegese com a visão de fé, ou melhor, conforme o ensinamento da Dei Verbum 12, que a própria exegese se desenvolva na moldura da fé, de modo que seus resultados possam ser mais diretamente postos em relação com a fé, a teologia e a espiritualidade. Exigese, por conseguinte, cultura bíblica, estudo sério, leitura orante, que integre exegese científica e fé. Se o que condicionou o aparecimento do fundamentalismo foi em parte a exegese liberal, é então a superação desta

\footnotetext{
${ }^{57}$ Cf. M. Amerise, "Cultura biblica e fondamentalismo non vanno d'accordo"; L. Diotallevi, "La conoscenza delle Scritture. Chi, quando, dove e come", in L'Osservatore Romano (edição quotidiana on line), 28-29 de abril de 2008.
} 
exegese por uma exegese crente que pode oferecer uma resposta à busca de Deus nas Escrituras e pode dar segurança (não falsa, mas real) diante das interpelações que a cultura faz à consciência cristã.

\section{Résumé}

L'article a en vue la présentation du fondamentalisme chrétien à la lumière de critères théologiques et bibliques. Après la description de son origine e de son développement, le travail synthétise et systématise sa doctrine, en approfondissant ses assertions et ses présuppositions. Ensuite, l'article réfléchit sur les problèmes principaux qui s'y impliquent. Finalement, sont montrées des pistes qui puissent aider à surmonter les problèmes qui sont à la base de ce fénomène.

\section{Maria de Lourdes Corrêa Lima}

Professora da PUC-Rio,

Profesorra do Instituto Superior de Teologia da Arquidiocese do RJ, Doutora em Teologia Bíblica pela Pontifícia Universidade Gregoriana

(Roma). 